\title{
EDITORIAL
}

\section{Introduction to the Special Section on the Psychology of Security}

\author{
Veronica Hopner, Darrin Hodgetts, Stuart Carr, Rhys Ball, \\ Nick Nelson, and Kerry Chamberlain \\ Massey University-Albany
}

Concerns regarding human security arguably define the contemporary world. Such concerns relate to the human desire to live with "freedom from want" and "freedom from fear" (United Nations System Task Team, 2012). There are significant challenges for contemporary human security that have emerged with processes of globalization, climate change, migration, population growth, violent extremism, transnational crime, constantly developing technologies, poverty, and inequality. More than ever perhaps, it is essential to consider the importance of economics, livelihoods, ecology, health, politics, and society when we seek to better understand human security. However, the dominant focus in psychology has remained relatively fixed on individual needs, perspectives, and experiences.

Security has long been an object of study within the discipline of psychology. With notable exceptions related to issues of the environment, culture, and society that appear in this special section, our disciplinary approaches have tended to approach security rather narrowly as an individualized process. As a discipline, we have primarily focused on understanding and supporting secure minds, thoughts, emotions, and identities, in essence a stable selfhood that grows in a stable or secure personal environment. Beginning with a North American humanistic perspective, security was initially theorized in psychology as requiring a blending of fundamental needs as well as personality development to create different levels of secure personhood (Maslow, 1942). Psychoanalytic thinkers have posited relational attachments as central to developing the psychic organization needed for this secure sense of self (Ainsworth \& Ainsworth, 1958; Bowlby, 1958; Fairbarin, 1952; Klein, 1927). Primarily, it was considered that successful emotional and social development results from positive attachment experiences in both childhood and adulthood.

This notion of the secure personhood has permeated other nation states beyond the United States and Europe, where the focus has tended to remain on individualistic aspects of personal security. As such, cross-cultural psychologists have also considered security in terms of people's internal psychological processes through attention on developmental perspectives (Mesman, van Ijzendoorn, \& Sagi-Schwartz, 2016), psychological needs (Malka, Soto, Inzlicht, \& Lelkes, 2014), and moral values (Schwartz, 2012).

(D) Veronica Hopner, Darrin Hodgetts, and Stuart Carr, School of Psychology, Massey UniversityAlbany; Rhys Ball and Nick Nelson, Centre for Defence and Security Studies, Massey UniversityAlbany; Kerry Chamberlain, School of Psychology, Massey University-Albany.

Correspondence concerning this article should be addressed to Veronica Hopner, School of Psychology, Massey University-Albany, Private Bag 102904, North Shore Mail Centre, Auckland 0745, New Zealand. E-mail: v.hopner@massey.ac.nz 
Relational attachments and developmental and psychological processes have also remained a primary object of study for social psychologists who have concentrated on how individuals secure personhood or identity through belonging and attachments to various social groups (Hogg \& Abrams, 1988; Tajfel \& Turner, 1986). Primarily, a sense of psychological security is predicated on group membership. Cognitive theorists have an alternative focus but remain wedded to individualistic conceptions about psychological security. Their view examines neuroscientific understandings of human experience and people's thoughts within decision-making processes, especially around risks and threats (Schneier, 2008). In essence, psychological security is seen as a cognitive process dependent on subjective beliefs and views of reality albeit influenced by collective and often historical experiences in particular sociocultural contexts (Bar-Tal \& Jacobson, 1998).

Russian psychologists in turn have moved away from a relatively individualistic understanding of psychological security. They have approached the psychology of security as an area of research that also considers the situational and collective experiences of both ethnic groups and national populations. From this perspective, security is achieved through having secure employment, being loved and desired, and having law and order as well as cultural and national safety (Zotova, 2011). Zinchenko (2011), for instance, argued that psychological security is best viewed as a system that links individuals to the security of a particular society. A consciousness of security for people within nations is seen as typified by various factors, including culture, history, economics, politics, ethnic experiences, and processes (Dontsov \& Perelygina, 2013; Zinchenko, 2011; Zinchenko \& Zotova, 2014; Zotova, 2011). Hence, "security is a condition of a person according to which he/she can satisfy basic needs for self-preservation and perception of being secure (psychologically) in society" (Dontsov, Zinchenko, \& Zotova, 2013, p. 99, emphasis added).

Indigenous theorists have further extended understandings of psychological security beyond internal mental processes, relationships with others, or social systems. Psychological security is thought to be created and maintained through location in family and tribal groups and connections to ancestral lands and with landscape features that provide the necessities of a secure life, such as rivers, mountains, and oceans (Mutu, 2005). From this perspective, psychological security can be seen as being entwined with spiritual connectedness and within temporal dimensions of the past, present, and future (cf. King, Hodgetts, Rua, \& Morgan, 2017; Marsden, 2003). As such, the psychology of security is bound in the vitalization of cultural practices and in the privileging of indigenous institutions, ways of knowing, and knowledge production (Kaya, 2014; Kaya \& Kale, 2016).

More work of this kind is needed to broaden out the engagements of psychologists with issues of security. In this special section, we offer two further contributions to this effort. Daniel Bar-Tal (2020) argued that "security is an essential precondition of an ordered existence for an individual, a collective and a societal system." In doing so, he located security conceptually within a sociopsychological framework and illustrated how political leaders use messages of fear and insecurity to claim and maintain their own political authority. Such political leaders construct threats as coming from within society (minority groups) or external groups (immigrants) to challenge the physical safety, economic security, as well as cultural and social integrity of the local population. These constructions of risk and threat damage possibilities for political inclusiveness and social participation and work to increase racism, discrimination, ethnocentrism, and xenophobia, which are also factors in reducing psychological security. In his contribution to growing dialogues regarding psychological secu- 
rity in our discipline, Bar-Tal highlighted that exercising political authority that is grounded in a security-based agenda increases possibilities for authoritarian regimes, and in turn, possibilities of nondemocratic legislation, limits of freedom of speech and association, and greater control of legal and judicial systems. Such actions render dissenting voices less secure.

Autocratic social relations are also discussed in the second contribution by Coelho, Cordeiro, and Massola (2020). Perceptions of security are framed in this article in the context of women's political participation in addressing the multiple insecurities associated with mining activities in Brazil. These authors recounted how contemporary mining practices disrupt local economic and social structures and contribute to increased insecurities in housing, income, freedom of assembly and expression, health, education, and the environment. Through an engagement with the political activism of Brazilian women, Coelho and colleagues (2020) demonstrated how psychologists can do more than just document such growing insecurities. These authors foregrounded the importance of scholar activists and the communities with whom they engage working together to regain a psychological sense of security and to cultivate a greater consciousness about material conditions and insecurities of everyday lives that are impacted by mining. In doing so, they resignify their relationship with the state and act to resecure their rights as citizens.

Finally, in increasingly insecure environments, such as that being presently experienced in Brazil, the psychological processes of engaging with today's security challenges are complex and diverse. Wider research from international perspectives that address contemporary security issues from new approaches within psychology is necessary. It is crucial that we as a discipline engage more fully with how people, groups, and societies psychologically understand and manage both insecurity and security. We hope that this special section is useful to other psychologists who are seeking an approach to psychological security that recognizes that such security is entwined with issues of health, stable ecologies, thriving economics, cultural integrity, inclusive politics, and safe nations.

These very themes are relevant to, and discernible in, the remaining contributions in this journal issue. We have an article focused on intercultural contact and cultural identity for Muslim immigrants and a further article on promoting mental health in the workplace. The latter in turn is a precursor to another forthcoming special issue on access to decent work for all. Like human security, decent work is an element in the United Nations Sustainable Development Goals. The Sustainable Development Goals are supported by this journal and by the Division. They are inherently linked to International Perspectives in Psychology.

\section{References}

Ainsworth, M. D. S., \& Ainsworth, L. H. (1958). Measuring security in personal adjustment. Toronto, ON, Canada: Canada University of Toronto Press.

Bar-Tal, D. (2020). Creating fear and insecurity for political goals. International Perspectives in Psychology, Practice, Consultation, 9, 5-17. http://dx.doi.org/10.1037/ ipp0000113

Bar-Tal, D., \& Jacobson, D. (1998). A psychological perspective on security. Applied Psychology, 47, 59-71. http://dx.doi.org/10.1111/j.1464-0597.1998.tb00013.x

Bowlby, J. (1958). The nature of the child's tie to his mother. The International Journal of Psychoanalysis, 39, 350-373.

Coelho, P. S., Cordeiro, M. P., \& Massola, G. M. (2020). Effects of female participation on insecurity in a mining area. International Perspectives in Psychology, Research, Practice, Consultation, 9, 18-35. http://dx.doi.org/10.1037/ipp0000121 
Dontsov, A. I., \& Perelygina, E. B. (2013). Tense situations and the significance of stability for psychological security. Psychology in Russia: State of the Art, 6, 4-15.

Dontsov, A. I. I., Zinchenko, Y. P., \& Zotova, O. Y. (2013). Notions of security as a component of students' attitude towards money. Procedia: Social and Behavioral Sciences, 86, 98-103. http://dx.doi.org/10.1016/j.sbspro.2013.08.532

Fairbarin, W. R. D. (1952). Psychoanalytic studies of the personality. London, UK: Tavistock Publications in collaboration with Routledge \& Kegan Paul Ltd.

Hogg, M. A., \& Abrams, D. (1988). Social identification: A social psychology of intergroup relations and group processes. London, UK: Routledge.

Kaya, H. O. (2014). Revitalizing African indigenous ways of knowing and knowledge production. In M. Woons \& K. L. Belgium (Eds.), Restoring indigenous selfdetermination (pp. 88-94). Bristol, UK: E-International Relations.

Kaya, H. O., \& Kale, S. E. (2016). African indigenous institutions and contemporary global security. Journal of Social Sciences, 46, 114-122. http://dx.doi.org/10.1080/ 09718923.2016.11893518

King, P., Hodgetts, D., Rua, M., \& Morgan, M. (2017). Disrupting being on an industrial scale: Towards a theorization of Māori ways-of-being. Theory and Psychology, 27, 725-740. http://dx.doi.org/10.1177/0959354317733552

Klein, M. (1927). Symposium on child analysis. International Journal of Psychoanalysis, 8, 339-370.

Malka, A., Soto, C. J., Inzlicht, M., \& Lelkes, Y. (2014). Do needs for security and certainty predict cultural and economic conservatism? A cross-national analysis. Journal of Personality and Social Psychology, 106, 1031-1051. http://dx.doi.org/10.1037/ a0036170

Marsden, M. (2003). The woven universe: Selected writings of Rev. Māori Marsden. Otaki, New Zealand: Estate of Rev. Māori Marsden.

Maslow, A. (1942). The dynamics of psychological security-insecurity. Journal of Personality, 10, 331-344. http://dx.doi.org/10.1111/j.1467-6494.1942.tb01911.x

Mesman, J., van Ijzendoorn, M. H., \& Sagi-Schwartz, A. (2016). Cross-cultural patterns of attachment. In J. Cassidy \& P. R. Shaver (Eds.), Handbook of attachment: Theory, research, and clinical applications (pp. 852-877). New York, NY: Guilford Press.

Mutu, M. (2005). In search of the missing Māori links-Maintaining both ethnic identity and linguistic integrity in the revitalization of the Māori language. International Journal of the Sociology of Language, 2005, 117-132. http://dx.doi.org/10.1515/ijs1.2005.2005 .172 .117

Schneier, B. (2008). The psychology of security. AFRICACRYPT'08 Proceedings of the Cryptology in Africa. First International Conference on Progress in Cryptology (pp. 50-79). Berlin, Germany: Springer.

Schwartz, S. H. (2012). An overview of the Schwartz theory of basic values. Online Readings in Psychology and Culture, 2, 11. http://dx.doi.org/10.9707/2307-0919.1116

Tajfel, H., \& Turner, J. C. (1986). An integrative theory of intergroup behaviour. In W. G. Austin \& S. Worchel (Eds.), The social psychology of intergroup relations (pp. 234-289). Monterey, CA: Brooks/Cole.

United Nations System Task Team. (2012). Towards freedom from fear and want: Human rights in the post-2015 agenda (Post-2015, UN Development Agenda). Retrieved from https://www.un.org/millenniumgoals/pdf/Think\%20Pieces/9_human_rights.pdf

Zinchenko, Y. P. (2011). Security psychology as a social systemic phenomenon. Psychology in Russia: State of the Art, 4, 307-315. http://dx.doi.org/10.11621/pir.2011.0019

Zinchenko, Y. P., \& Zotova, O. Y. (2014). Security in the worldview of Russians. Psychology in Russia: State of the Art, 7, 50-61.

Zotova, O. Y. (2011). Need for safety in different social and economic groups. Psychology in Russia: State of the Art, 4, 335-347. http://dx.doi.org/10.11621/pir.2011.0022

Received December 10, 2019

Accepted December 10, 2019 